\title{
STUDY SKILLS ACQUIRED BY UNIVERSITY ALUMNI: COUNTER-ANALYSIS OF THE CARDINAL STEFAN WYSZYŃSKI UNIVERSITY GRADUATES' CAREER SURVEY
}

\begin{abstract}
The career analysis conducted among the alumni of universities is dominated in Poland by the tendency to verify which competencies (demanded mostly by the labour market) they have acquired and how they have managed to cope with finding employment. The ability of studying is a rarely discussed problem, which is unjustifiably considered necessary only during the course of study. However, this ability leads to shaping the extent of academic thinking, also understood as a specific way of solving problems - not only purely academic ones but professional ones as well.

The author of the presented article, while referring to pedagogical concepts of S. Hessen and D. Benner, has developed a theoretical model of study skills and subsequently conducted its empirical verification by performing a repeated analysis of selected data obtained in 2016 during the Cardinal Stefan Wyszyński University graduates' career analysis.

The conducted replication has proved that, firstly, the exploration of study skills among the alumni has not been taken into account when examining careers of the graduates, which might have served as feedback regarding the modification of the education process at the university; secondly, it seems that the graduates have acquired study competence at least to a certain degree, which finds evidence in success achieved by most of them - i.e. finding employment; and, thirdly, satisfaction of completing studies is linked with the feeling of having the right competence and consequently with recommending the university to others.
\end{abstract}

Keywords: study skills, alumni, scientific thinking, problem solving.

\section{Introduction - monopolization of studying by the labour market}

In Poland, university graduates' career analysis is becoming an increasingly popular practice. However, it is most often conducted by internal university (higher education institution) cells, whose task is to monitor the quality of education (Ogólnopolski system...). One of the most important objectives of this research is to raise the level of education and to pursue increasingly better effects in this 
respect. It can therefore be stated that it is a good tool for self-development of university practices.

It may sound paradoxical to raise a question to what extent university graduates have acquired study skills while studying and to what extent these skills are indispensable for them after completing the course. In this article I will try to prove that the above-stated question has a deeper meaning than it seems at first glance.

It is quite a common view among academic teachers that in higher education the activity of studying is not highly appreciated. Although, in the European Higher Education Area there is a principle of observing European Dublin Descriptors which include the listing of skills and competencies for the students to master at specific levels of education - ultimately, it is the competencies closely related to the labour market and employers' expectations that serve as the right product of academic education. This conviction has been proved by international and Polish research projects conducted during the last decade, which were aimed at verifying, if higher education institutions fulfilled these very requirements (Larsen, et al., 2012). On this basis we may draw the assumption that study skills are considered an ephemeral - i.e. limited in time to the period of study - and instrumental capability, which means that it is used to intercede in acquiring specific labour market competencies (Kulpa-Puczyńska 2015).

The presented image should be complemented with the observation derived from academic education practice, demonstrating that students not only spend less time for the activity of studying but that they also cannot study. This is partly associated with the fact that in the course of their studies they undertake various efforts to sell experience and skills preferred by the labour market and employers, which often stands in opposition to studying. This fact also highly influences their expectations towards teachers and the university, aimed at providing them with practical application knowledge only.

\section{The theoretical model of studying}

Studying as a specific skill developed during the course of academic study is not a frequent subject of research analyses. To a certain extent it becomes understandable, if we assume that the activities of studying involve only a certain level and stage of education (academic education) and are strictly subordinated to that process of education. However, as Gettinger and Seibert (2002) claim, "study skills include the competencies associated with acquiring, recording, organizing, synthesizing, remembering, and using information. These competencies contribute to success in both non-academic (e.g. employment) and academic settings" (p. 350).

In pedagogy, the terms used to explain what studying actually is, include the following: "self-learning" (Bereźnicki 2009), "learning in depth" (Ciechanowska 2009) or "metacognition" (Zdybel 2015). Although there is a consensus that studying lays at the heart of academic education, it lacks a definition. With regard to this fact 
I will refer to the concept of a twentieth-century Russian pedagogue, Sergei Hessen, who in his work titled Podstawy pedagogiki (The basics of pedagogy) gives the highest level of education the task of mastering academic thinking. Such thinking is nowise reserved for researchers. In this respect he writes that: "Not all will become scholars of their profession and even not all will reach the highest level of academic education [...]. Science, however, should be approached by everyone [bolded by D.S.]. As there exists no twofold cognition - academic and 'ordinary' - but every cognition, provided it is true, is academic cognition. A child in the process of cognising, making his/her first observations of the reality and drawing conclusions out of it, is already unknowingly subject to the same laws and rules that govern the work of scholars. 'Academic thinking', 'academic education' are only higher levels of this process, whose initial stages include every-day deliberations and life experiences of a child" (Hessen 1997, pp. 280-281).

As the above-cited quotation implies that studying is "only" a higher level of academic thinking and, according to S. Hessen, it aims at "inculcating in a learner the method of academic cognition [bolded by D.S.], teaching him/her to discuss a problem in an academic manner and direct it on the way leading to the solution. A developed mind is not simply a strong mind - it is also a mind that is scientific and educated, a mind embraced by academic culture, capable of subordinating the arbitrariness of its thinking to the objective requirements of the method. It is a mind that has developed a taste for the truth and knows the direction of where the truth can be found" (ibidem, p. 297).

Despite the time gap separating us from the moment, when S. Hessen formulated his thoughts (the Polish version of The basics of pedagogy was published for the fist time in 1931), they have not at all become out of date. An important addition to this concept can be found in Dietrich Benner's works - devoted to academic education, where the emphasis is put on two elements: making use of negative experiences in the process of learning and teaching (Benner, English 2004; English 2013) and understanding the activity of studying as extending the horizon of thoughts which leads to critical thinking (Benner 2015, pp. 241-302). On this basis he proposes the theoretical model of studying demonstrated in the following diagram. 
Diagram 1. The theoretical model of studying

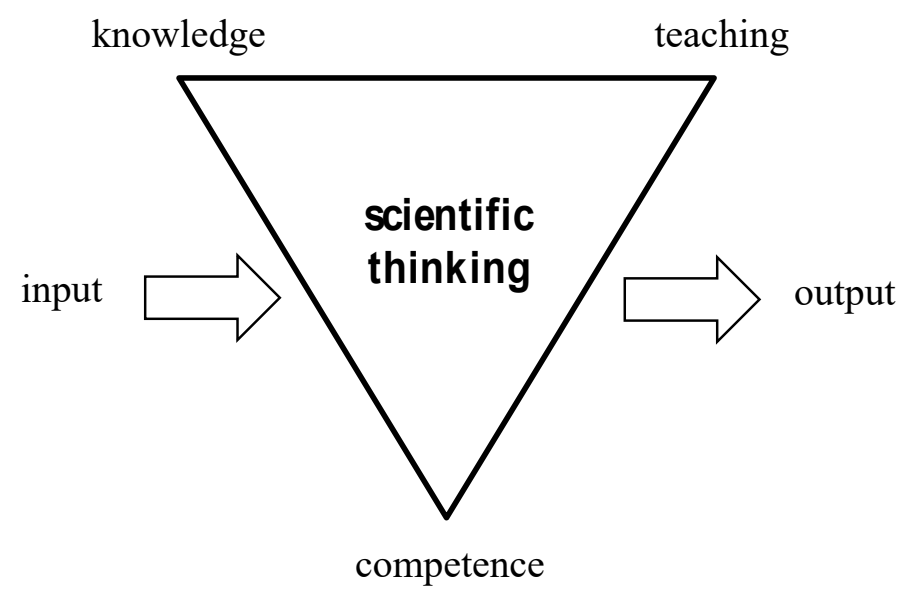

Source: own elaboration.

In the developed model studying is a non-observable variable (directly nonobservable), which is explained by the triad of the following terms: (1) teaching, (2) knowledge and (3) competence. They create a direct space where the activity of studying takes place achieving scientific thinking competence in the aforementioned sense of ability needed for everyone. Apart from this, studying is influenced by external factors identified by the terms: "input" and "output". The first term stands for legal regulations concerning education, the second concerns educational effects. A study aimed at the verification of the sketched model will be carried out in the remainder of this article.

\section{Description of the research project}

The above model of studying is a starting point for the following considerations. Its main goal is to verify the hypothesis that knowledge, teaching and competence are three important determinants of studying. The verification of this hypothesis has been conducted through a repeated calculation of raw data collected during 2014/2015 graduates' career analysis, carried out by the Career Center of UKSW (Raport z badania karier...).

The research has been conducted via the method of the diagnostic survey among last-year students of full-time and part-time program studies of the first and second degree, who submitted their diploma examination by 31 December 2015. For the purpose of the interview a questionnaire survey of 76 questions has been prepared, including single- and multiple-choice open-ended, semi-open-ended and closedended questions. The survey was divided into a general part addressed to all alumni, two separate parts for employed and unemployed graduates and a part for persons interested in continuing their education. Answer choices have been created with the help of Likert, Guttman and semantic differential scales. The study was supported with the technique of Computer Assisted Web Interviewing (CAWI). Unfortunately, 
the obtained results have proved to be unrepresentative, because the selection of samples was not random. Moreover, the proportions between the number of participants and the number of graduates from respective university departments were not maintained. Also for this reason no statistical measures were given.

The data (obtained as indicated above) were re-analysed in relation to the following research problems: (1) How do graduates assess their competence after completion of studies?, (2) How did graduates manage to find employment?, (3) What is graduates' attitude towards studying?, and (4) How, from the perspective of the labour market, do graduates valuate the studies at their former university?

The population of graduates of year 2014/2015 was 3689 persons. 2551 graduates (69.2 percent) declared in writing to participate in the study, of which 539 (14.6 percent) completed the interview questionnaires. The majority of respondents -75.5 percent - were women. Among the participants of the study 418 persons (77.6 percent) declared finding employment around 6 months after completion of studies. On the other hand, 121 persons (22.4 percent) remained without employment at that time.

\section{Presentation of the obtained results}

In order to answer the first study problem, there was one more question selected from the listing of survey questions, where the graduates, using a five-grade scale, had to mark which competencies they have acquired and which then have not. The list of competencies included 10 positions. In order to achieve a clearer picture, at the replication of the analysis four intermediate categories: 'I agree', 'I partially agree' and 'I disagree', 'I partially disagree', were merged into one: 'I have acquired it' and the respective 'I have not acquired it'. The obtained results, broken down to graduates with employment and without employment, have been presented in the following table.

Table 1. Acquired and non-acquired competencies divided into "with employment" and "without employment" (percent out of $\mathrm{N}$ in the row)

\begin{tabular}{|l|c|c|c|c|c|c|}
\hline \multirow{2}{*}{} & \multicolumn{3}{|c|}{ With employment } & \multicolumn{3}{c|}{ Without employment } \\
\cline { 2 - 7 } & $\begin{array}{c}\text { I have } \\
\text { not } \\
\text { acquired } \\
\text { it }\end{array}$ & $\begin{array}{c}\text { neither } \\
\text { yes } \\
\text { nor no }\end{array}$ & $\begin{array}{c}\text { I have } \\
\text { acquired } \\
\text { it }\end{array}$ & $\begin{array}{c}\text { I have } \\
\text { not ac- } \\
\text { quired it }\end{array}$ & $\begin{array}{c}\text { neither } \\
\text { yes nor } \\
\text { no }\end{array}$ & $\begin{array}{c}\text { I have } \\
\text { acquired } \\
\text { it }\end{array}$ \\
\hline $\begin{array}{l}\text { communica- } \\
\text { tion skill }\end{array}$ & 17.5 & 25.1 & 57.4 & 12.4 & 28.1 & 59.5 \\
\hline creativity & 28.0 & 28.0 & 44.0 & 19.0 & 31.4 & 49.6 \\
\hline
\end{tabular}




\begin{tabular}{|l|c|c|c|c|c|c|}
\hline & \multicolumn{2}{|c|}{ With employment } & \multicolumn{2}{c|}{ Without employment } \\
\cline { 2 - 7 } & $\begin{array}{c}\text { I have } \\
\text { not } \\
\text { acquired } \\
\text { it }\end{array}$ & $\begin{array}{c}\text { neither } \\
\text { yes } \\
\text { nor no }\end{array}$ & $\begin{array}{c}\text { I have } \\
\text { acquired } \\
\text { it }\end{array}$ & $\begin{array}{c}\text { I have } \\
\text { not ac- } \\
\text { quired it }\end{array}$ & $\begin{array}{c}\text { neither } \\
\text { yes nor } \\
\text { no }\end{array}$ & $\begin{array}{c}\text { I have } \\
\text { acquired } \\
\text { it }\end{array}$ \\
\hline $\begin{array}{l}\text { analytical } \\
\text { thinking }\end{array}$ & 26.1 & 26.1 & 47.8 & 21.5 & 34.7 & 43.8 \\
\hline $\begin{array}{l}\text { resistance } \\
\text { to stress }\end{array}$ & 26.6 & 26.3 & 47.1 & 17.4 & 34.7 & 47.9 \\
\hline $\begin{array}{l}\text { self-reliance } \\
\text { and accuracy }\end{array}$ & 13.6 & 17.7 & 68.7 & 10.7 & 19.8 & 69.4 \\
\hline $\begin{array}{l}\text { working in } \\
\text { a team }\end{array}$ & 20.8 & 19.1 & 60.0 & 19.0 & 21.5 & 59.5 \\
\hline $\begin{array}{l}\text { perseve- } \\
\text { rance and } \\
\text { consistency }\end{array}$ & 15.3 & 19.6 & 65.1 & 13.2 & 27.3 & 59.5 \\
\hline commitment & 17.5 & 16.5 & 66.0 & 14.0 & 30.6 & 55.4 \\
\hline $\begin{array}{l}\text { organization } \\
\text { of work }\end{array}$ & 20.6 & 19.1 & 60.3 & 19.0 & 25.6 & 55.4 \\
\hline $\begin{array}{l}\text { time } \\
\text { management }\end{array}$ & 22.0 & 23.9 & 54.1 & 24.0 & 28.1 & 47.9 \\
\hline
\end{tabular}

Source: own elaboration.

At least half of the respondents, both from the group with employment and without employment, declared that they have acquired the listed competencies. The forefront is occupied by self-reliance and accuracy, which was marked by 68.7 percent of the first group and 69.4 of the second. However, it is quite thoughtprovoking that a large percentage of the participants marked "neither yes nor no". After combining both groups, the percentage values range between 28.8 for creativity and $\mathbf{1 8 . 2}$ percent for the already mentioned self-reliance and accuracy. In general, it can be assumed that one third of respondents were not able to clearly state whether they have or have not acquired specific competencies.

To ensure the reliability of the declarations submitted by the graduates on having or not having certain competencies, answers to the question about the missing competency were calculated again. The list of competencies proposed for selection included the same competencies as before, however, it was enhanced by the position "other", where the respondent could enter their own content. The collected results have been presented in the following figure. 
Figure 1. Missing competencies broken down to graduates with and without employment

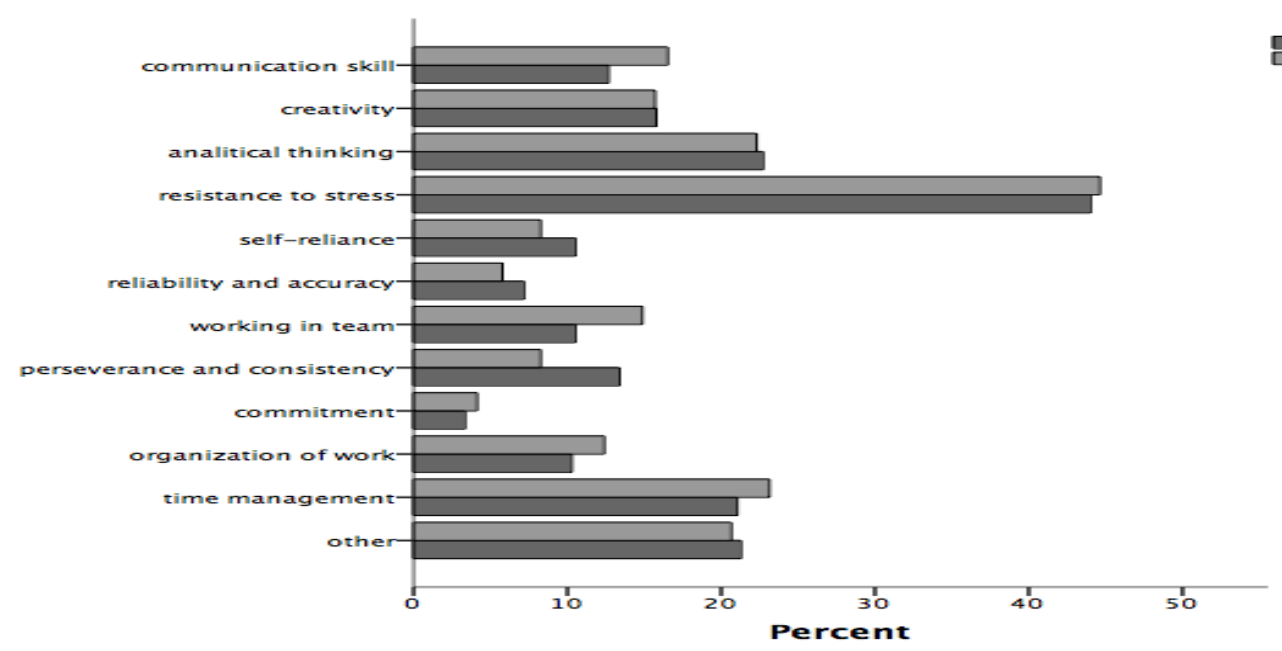

Source: own elaboration.

In the above figure, apart from the fact that the average values are around 15 percent, attention can be drawn to quite large convergence of views presented by graduates with and without employment. A clearly outstanding range is the lack of resistance to stress, which was marked by approximately 44 percent of respondents of both groups. It is somewhat surprising, because in the question concerning the possessed competencies the total 47.3 percent of respondents marked that they have acquired this competency. Nonetheless, the least deficit seems to concern commitment, which was marked by only 3.3 percent in the group with employment and 4.1 in the group (yet) without employment.

The second study problem was meant to verify whether the graduates have acquired the competency of solving problems, which is integrally attributed to the competency of studying. For the purpose of the replication analysis, one question referring to the activities undertaken to find employment was selected from the list of survey questions. The obtained results broken down to graduates who managed to find employment and those who remain (yet) without employment, have been presented in the following figure. 
Figure 2. Ways of employment search broken down to employed and unemployed graduates

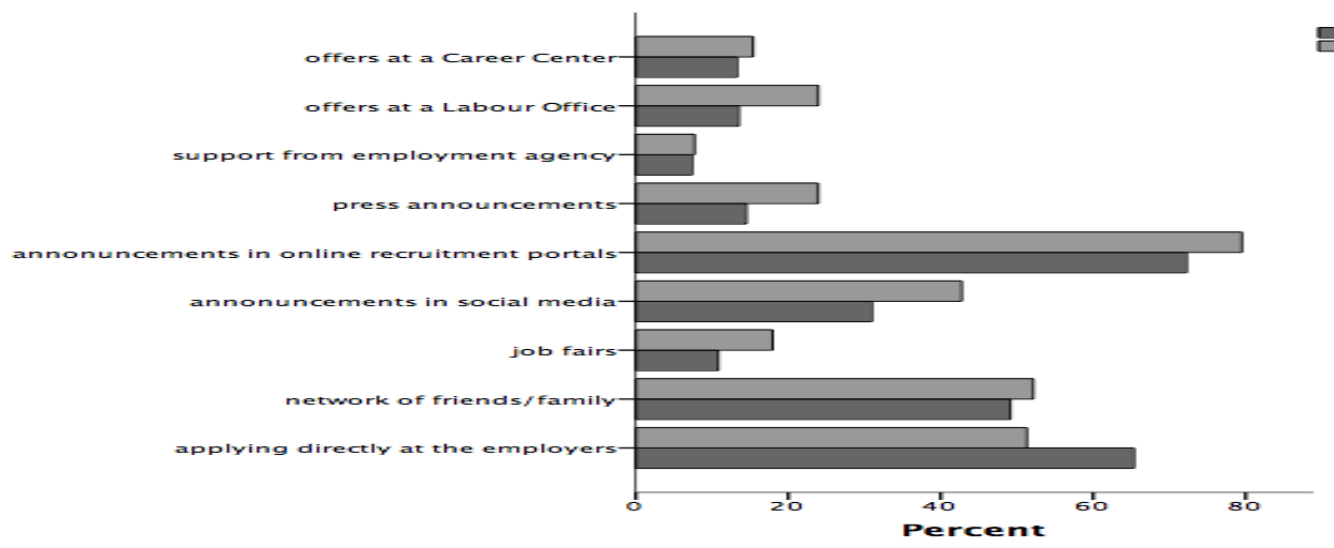

Source: own elaboration.

As it can be seen in the above figure, both groups of graduates have taken similar actions while searching for employment. Browsing online recruitment portals has been a dominant measure. This action was taken more frequently by graduates being currently without employment ( 79.5 percent) over the currently employed ones (72.2 percent). The latter, however, were more keen (65.4 percent), than their colleagues (51.3 percent), to apply directly at the employers.

In the next study problem the task was to acquire information about graduates' mindset towards further studying. It seems that the proper indicator of this mindset has been framed by the answers to survey questions concerning the objectives of professional career, which were given by both graduates with and without employment.

Figure 3. Objectives of professional career broken down to employed and unemployed graduates

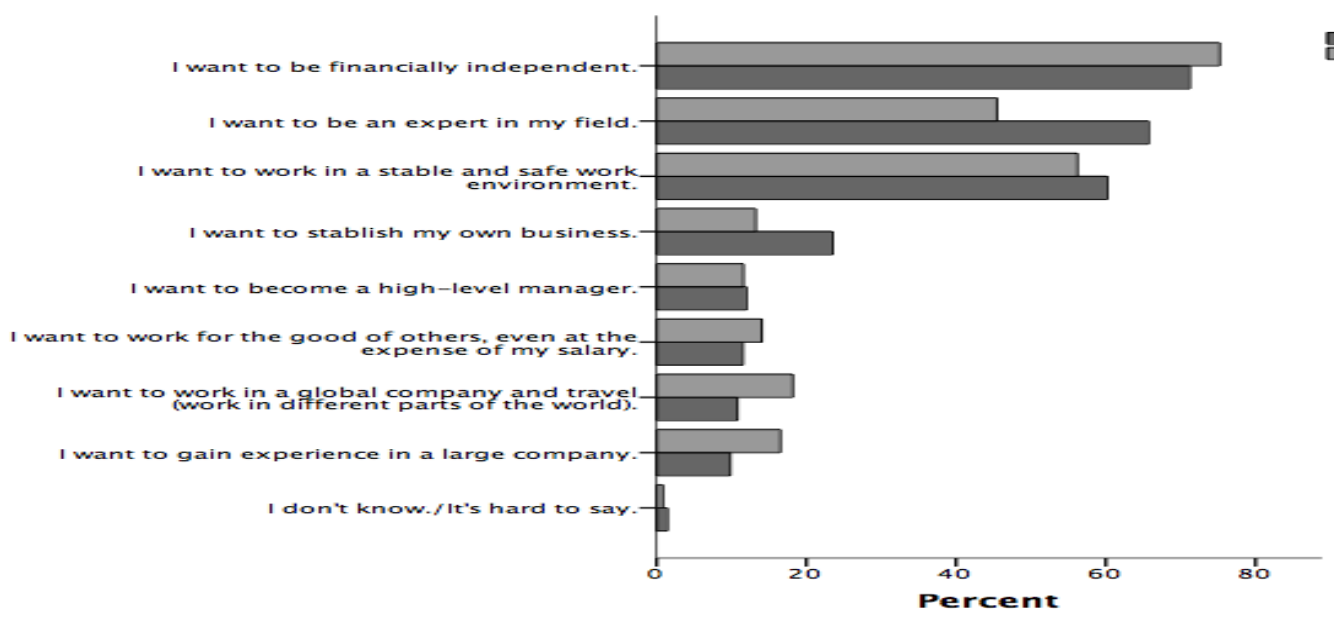

Source: own elaboration. 
The total 72.1 percent of graduates have declared that their most important objective is to gain financial independence. The difference between the group of the employed and the unemployed amounted to only 4 percentage points. From the perspective of the analysed problem of readiness for further studying, it is noteworthy that the second place is held by the willingness to become an expert in the studied field of expertise, which was marked by 61.2 percent of respondents. This is also the area of the largest discrepancy between the two groups. The difference was as much as 20.2 percentage points to the disadvantage of the unemployed graduates.

The last study problem concerns the evaluation of the former university in terms of three ranges distinguished in the theoretical model, i.e. knowledge, teaching and competence, from the perspective of the labour market. In order to receive graduates' feedback on the above-mentioned topics, one question was selected from the list of survey questions for the purpose of the replication analysis. The opinions of the graduates have been presented in the following table.

Table 2. The evaluation of the dimensions of studying from the perspective of the labour market (whole sample)

\begin{tabular}{|l|c|c|c|c|}
\cline { 2 - 5 } \multicolumn{1}{c|}{} & I disagree & $\begin{array}{c}\text { neither yes } \\
\text { nor no }\end{array}$ & I agree & Total \\
\hline $\begin{array}{l}\text { Experience gained during } \\
\text { studies prepared me to enter } \\
\text { the labour market. }\end{array}$ & $38.2 \%$ & $30.2 \%$ & $31.5 \%$ & $100.0 \%$ \\
\hline $\begin{array}{l}\text { The course of study allowed } \\
\text { me to gain knowledge requi- } \\
\text { red by employers. }\end{array}$ & $34.3 \%$ & $29.1 \%$ & $36.5 \%$ & $100.0 \%$ \\
\hline $\begin{array}{l}\text { The course of study allowed } \\
\text { me to gain skills required in } \\
\text { the labour market. }\end{array}$ & $40.3 \%$ & $29.5 \%$ & $30.2 \%$ & $100.0 \%$ \\
\hline
\end{tabular}

Source: own elaboration.

The collected data are deployed more or less equally in all three dimensions. However, it is worrying that each time nearly 30 percent of the respondents marked that they did not have an own opinion. Most graduates (40.3 percent) did not comply with the statement that the course of study enabled them to acquire skills required in the labour market. On the other hand, the most appreciated statement was: "The course of study allowed me to gain knowledge required by employers" - 36.5 percent.

In order to delve deeper into the reasons behind such choices, the examined sample was divided in a different way than before - i.e. into those who would recommend their former university as a good place to study and those who would not recommend it. It is encouraging that the Cardinal Stefan Wyszyński University 
(UKSW) has been recommended by the vast majority of respondents: 81.3 percent out of the employed graduates and 77.7 percent out of the (yet) unemployed ones. Taking aside the reasons for which some graduates would not recommend the university, I will concentrate on the evaluation given by both groups to the abovementioned dimensions of studying. The obtained results have been presented in the following table.

Table 3. The evaluation of the dimensions of studying from the perspective of those who would recommend the university and those who would not recommend it

\begin{tabular}{|c|c|c|c|c|}
\hline & \multirow{3}{*}{$\begin{array}{c}\text { Experience } \\
\text { gained dur- } \\
\text { ing studies } \\
\text { prepared } \\
\text { me to enter } \\
\text { the labour } \\
\text { market. } \\
29.3 \% \\
\end{array}$} & \multirow{3}{*}{$\begin{array}{c}\text { The course of } \\
\text { study allowed } \\
\text { me to gain } \\
\text { knowledge } \\
\text { required by } \\
\text { employers. } \\
26.7 \%\end{array}$} & \multirow{3}{*}{$\begin{array}{c}\text { The course } \\
\text { of study } \\
\text { allowed me } \\
\text { to gain skills } \\
\text { required in } \\
\text { the labour } \\
\text { market. } \\
32.3 \% \\
\end{array}$} \\
\hline & & & & \\
\hline \multirow{3}{*}{$\begin{array}{l}\text { Graduates } \\
\text { who would } \\
\text { recommend } \\
\text { the university }\end{array}$} & I disagree & & & \\
\hline & $\begin{array}{l}\text { neither yes } \\
\text { nor no }\end{array}$ & $33.6 \%$ & $29.7 \%$ & $31.8 \%$ \\
\hline & I agree & $37.1 \%$ & $43.5 \%$ & $35.9 \%$ \\
\hline \multirow{3}{*}{$\begin{array}{l}\text { Graduates } \\
\text { who would not } \\
\text { recommend } \\
\text { the university }\end{array}$} & I disagree & $75.2 \%$ & $65.7 \%$ & $73.3 \%$ \\
\hline & $\begin{array}{l}\text { neither yes } \\
\text { nor no }\end{array}$ & $16.2 \%$ & $26.7 \%$ & $20.0 \%$ \\
\hline & I agree & $8.6 \%$ & $7.6 \%$ & $6.7 \%$ \\
\hline
\end{tabular}

Source: own elaboration.

The above table shows that those who would not recommend the university also evaluate it negatively. Broken down to individual dimensions it is depicted as follows: experience - 75.2 percent; knowledge -65.7 percent and skills -73.3 percent. In contrast to this, among those who would recommend UKSW for studying three possible options of answers are broken down quite equally, where 43.5 percent of respondents believe that studies gave them the knowledge required by employers.

The non-recommending respondents gave vent to their frustration also in the question, where they were asked to give their opinion on whether successful completion of studies at UKSW can influence finding employment. The results have been presented in the following table. 
Table 4. The evaluation of reputation of UKSW broken down to those who would recommend the university and those who would not recommend it

\begin{tabular}{|l|c|c|c|}
\cline { 2 - 4 } \multicolumn{1}{c|}{} & $\begin{array}{c}\text { Graduates who } \\
\text { would recommend } \\
\text { the university }\end{array}$ & $\begin{array}{c}\text { Graduates } \\
\text { who would not } \\
\text { recommend the } \\
\text { university }\end{array}$ & Total \\
\hline I disagree & $22.6 \%$ & $62.9 \%$ & $30.4 \%$ \\
\hline $\begin{array}{l}\text { neither yes } \\
\text { nor no }\end{array}$ & $27.2 \%$ & $24.8 \%$ & $26.7 \%$ \\
\hline I agree & $50.2 \%$ & $12.4 \%$ & $42.9 \%$ \\
\hline
\end{tabular}

Source: own elaboration.

The table clearly depicts that the previously expressed disapproval against the efficiency of studies has been maintained also in respect to the evaluation of reputation of the university in the labour market. Which, in fact, is in contradiction with the collected data, if the same question is analysed within the division of the employed and unemployed graduates.

Table 5. The evaluation of reputation of UKSW broken down to the employed and unemployed graduates

\begin{tabular}{|l|c|c|c|}
\cline { 2 - 4 } \multicolumn{1}{c|}{} & With employment & $\begin{array}{c}\text { Without } \\
\text { employment }\end{array}$ & Total \\
\hline I disagree & $30.9 \%$ & $28.9 \%$ & $30.4 \%$ \\
\hline $\begin{array}{l}\text { neither yes } \\
\text { nor no }\end{array}$ & $25.1 \%$ & $32.2 \%$ & $26.7 \%$ \\
\hline I agree & $44.0 \%$ & $38.8 \%$ & $42.9 \%$ \\
\hline Total & $100.0 \%$ & $100.0 \%$ & $100.0 \%$ \\
\hline
\end{tabular}

Source: own elaboration.

The given answers are spread quite evenly, where the most graduates of both groups (i.e. those without employment and without it) agree with the statement that the completion of the discussed higher education institution can have influence on finding employment. This suggests that the dissatisfaction with studying at UKSW is not necessarily associated with the forefront effect, which is finding employment in quite a short time after the completion of studies. Unfortunately, in the survey the dissatisfied were asked about the reasons for their dissatisfaction through questions focused around gaining experience required in the labour market, and not around teaching or studying. Moreover, the satisfied ones were not asked about the reasons of their satisfaction. 


\section{Conclusion}

The graduates' career analysis gives higher education institutions an opportunity of staying aware of the effectiveness of their process of academic education. Unfortunately, this effectiveness is usually recognized in a very narrow realm and is associated with finding employment by the alumni in the shortest possible time after the completion of studies. The latter aspect is often referred to as the main and the only measure of the quality of education, which is seen as the source of prestige of a given higher education institution. A scarcely identified aim of surveying the alumni are study skills, which are indispensable not only during academic education but also after its completion, functioning as the ability of academic thinking and an appropriate foundation of a professional career.

In the above article the data obtained in UKSW graduates' career analysis have been re-analysed in relation to the adopted model of studying. It appeared that the survey used to carry out this study has been developed according to the dominating scheme of perceiving the effectiveness of higher education through the prism of graduates' operability in the process of finding employment. Although the author managed to select certain questions and conduct the replication of the analysis in the perspective of studying, the obtained results cannot be considered as fully satisfactory. They indicate that graduates have acquired, at least to some extent, study skills, i.e. academic thinking, however, its in-depth verification requires conducting a separate test or refocusing the existing graduates' career analysis.

\section{References}

Benner D. (2015). Allgemeine Pädagogik. Eine systematisch-problemgeschichtliche Einführung in die Grundstruktur pädagogischen Denkens und Handelns. Weinheim-Basel: Beltz Juventa.

Benner D., English A. (2004). Critique and Negativity. „Journal of Philosophy of Education" 38, pp. 409-428.

Bereźnicki F. (2009). Zagadnienia dydaktyki szkoły wyższej. Szczecin: Pedagogium Wydawnictwo OR TWP.

Ciechanowska D. (2009). Uczenie się głębokie jako efekt studiowania. In: Ciechanowska, D. (ed.). Uwarunkowania efektów ksztatcenia akademickiego. Szczecin: Pedagogium Wydawnictwo OR TWP, 111-129.

English A. (2013). Discontinuity in Learning. Dewey, Herbart, and Education as Transformation. Cambridge University Press.

Gettinger M., Seibert J.K. (2002). Contributions of study skills to academic competence. „School Psychology Review” vol. 31, no. 3, 350-565.

Hessen S. (1997). Podstawy pedagogiki. Warszawa: Wydawnictwo Żak.

Kulpa-Puczyńska A. (2015). The model of cooperation with employers as the support measure for the development of entrepreneurial university potencial. In: HEAd'15. 
Proceedings of the 1st International Conference on Higher Education Advances, Valencia: Universitat Politècnica de València, pp. 326-333.

Larsen Ch., Hasberg, R., Schmid A., Atin E., Brzozowski J. (eds) (2012). Skills monitoring in European regions and localities. State of the art and perspectives. R. Hampp Verlag: München.

Ogólnopolski system monitorowania ekonomicznych losów absolwentów szkót wyższych. Retrieved January 10, 2017, available at http://absolwenci.nauka.gov.pl/ (2017.04.12).

Raport z badania karier zawodowych absolwentów UKSW 2014/2015 (2016). Unpublished document.

Zdybel D. (2015). Metapoznanie - ukryty wymiar kompetencji uczenia się. In: Uszyńska-Jarmoc J., Bilewicz M. (ed.). Kompetencje kluczowe dzieci i młodzieży. Teoria i badania. Warszawa: Wydawnictwo Akademickie Żak, pp. 54-70.

\section{UMIEJĘTNOŚĆ STUDIOWANIA U ALUMNÓW UNIWERSYTETU. POWTÓRNA ANALIZA BADANIA KARIER ABSOLWENTÓW UNIWERSYTETU KARDYNAŁA STEFANA WYSZYŃSKIEGO}

Streszczenie: W badaniach karier alumnów uniwersytetów i uczelni wyższych w Polsce dominuje tendencja sprawdzania, jakimi kompetencjami dysponują oni z perspektywy rynku pracy i jak poradzili sobie z zadaniem znalezienia zatrudnienia. Rzadko podejmowanym problemem jest kwestia umiejętności studiowania, którą niesłusznie uważa się za potrzebną wyłącznie w okresie studiów. Tymczasem umiejętność ta prowadzi do ukształtowania myślenia naukowego rozumianego jako specyficzny sposób rozwiązywania problemów nie tylko stricte naukowych, lecz również nienaukowych. W związku z tym stanowi ona warunek osiągnięcia sukcesu w obu sferach - akademickiej i pozaakademickiej (np. zawodowej).

W prezentowanym artykule autor, odwołując się do koncepcji pedagogicznych S. Hessena i D. Bennera, skonstruował model teoretyczny umiejętności studiowania, a następnie poddał go empirycznej weryfikacji przez powtórną analizę danych zgromadzonych podczas badania karier absolwentów Uniwersytetu Kardynała Stefana Wyszyńskiego w Warszawie w 2016 roku.

W rezultacie przeprowadzonej replikacji okazało się, że, po pierwsze, przy badaniu karier absolwentów nie uwzględnia się eksploracji umiejętności studiowania u alumnów, co mogłoby dostarczyć informacji zwrotnej odnośnie do modyfikacji procesu kształcenia w uczelni; po drugie, absolwenci posiedli umiejętność studiowania przynajmniej w pewnym zakresie, czego dowodem jest osiągnięty przez większość sukces - zdobycie zatrudnienia, i po trzecie, satysfakcja z ukończonych studiów ma związek z poczuciem kompetencji i w konsekwencji rekomendowaniem uczelni innym.

Słowa kluczowe: umiejętność studiowania, alumni, myślenie naukowe, rozwiązywanie problemów. 
Dariusz Stępkowski - Ph.D., associate professor of the Cardinal Stefan Wyszyński University in Warsaw, Poland. His main publications: Herbart znany i nieznany (co-editor, 2006), Pedagogika ogólna i religia (2010), Wychowanie i kształcenie w systemach politycznych (co-editor, 2012), Bildung und Erziehung in politischen Systemen (co-editor, 2012), Religion long forgotten (co-editor, 2014), Bildung-Moral-Demokratie (co-author, 2015), Pedagogika wobec duchowości - duchowość wobec pedagogiki (co-editor, 2016). Research interests: philosophy of education/general pedagogy, high school teaching theory, moral education. E-mail-address: d.stepkowski@uksw.edu.pl. 